\title{
Obstinate and Unmovable? The EU vis-à-vis Myanmar via EU- ASEAN
}

\author{
Ludovica Marchi Balossi-Restelli ${ }^{1}$ \\ University of Reading \\ Imb7979@gmail.com
}

\begin{abstract}
$^{2}$
This article examines continuity and change in the European Union's interactions with the Association of South East Asian Nations (ASEAN) with regard to Myanmar. As the EU has used its connections with ASEAN to raise its concerns around Myanmar, the Association's behaviour also comes into focus. This investigation is linked to the evolution of the EU in world affairs via its political ties to ASEAN. It concentrates on the rather abrupt change introduced by the reform process launched in 2011-12, which marked the beginning of a new phase. The EU's concern that the Myanmar issue not destabilise its relations with ASEAN has remained constant, however changes in the dialogue can be seen as forming three distinct phases. It is maintained that the aspiration to escape from pervasive China and the desirability of attracting new partners were the catalyst for these changes. Official documents from the EU, the European Commission, and European Council Conclusions and Common Positions, declarations issued at ASEAN, Asia-Europe and other meetings, together with secondary sources and interviews conducted mostly in Myanmar, contribute to this work. While many scholars have hinted at the extent to which the issue of Myanmar has been problematic to the EU-ASEAN links, there has been no emphasis on the positive effect that Myanmar has had on EU-ASEAN relations. This research illuminates the extent to which this issue has conversely helped to reinforce the long-lasting EU-ASEAN relationship.
\end{abstract}

Key words: European Union, EU-ASEAN, ASEM, Myanmar, foreign policy analysis

\section{Introduction}

The Republic of the Union of Myanmar has recently generated increasing attention among scholars and observers alike. 3 The 2011-12 reform process, the 2012 by-elections and the transfer of power to a civilian, military-sponsored government marked abrupt changes. President Thein Sein (a former general, Prime Minister since 2007, and President since March 2011) appeares to be the architect of the transformation. The by-elections resulted in a landslide victory for the government's opposition party, the National League for Democracy (NLD), led by Nobel Peace laureate, Daw Aung San Suu Kyi. Sein's government released a number of political prisoners, concluded ceasefire arrangements with armed groups in the ethnic regions, signed peace agreements, made efforts to eliminate the use of

\footnotetext{
${ }^{1}$ The shortened pen-name 'Marchi' is used in the text and references.

2 A first version of this article was prepared for the 2013 EUSA AP Annual Conference, Macau, 17-18 May, 'Reassessing the EU-Asia Pacific Relationship in the context of the EU crisis.' The author thanks the participants, John Leslie and Pascaline Winand, and also the participants in the discussion of this last version, in January 2014, at Singapore Management University, School of Social Science, in particular Paul Evans, Clara Portela and William Tov, and ANZJES' anonymous reviewers for their constructive comments.

3 For the country profile, see the EC/Burma/Myanmar Strategy Paper (2007-2013), pp. 5-46. <http://eeas.europa.eu/myanmar/csp/o7_13_en.pdf>, accessed 19 September 2013.
} 
forced labour, recognised labourers' right to strike, and amended the censorship laws. ${ }^{4}$ In January 2013, an international conference was organized in Myanmar, at which the Sein government's timetable for reform over the next three years was unveiled. Yet, the government is facing challenges including the need to reform the Constitution, which preserves the military's supremacy over the Cabinet and Parliament 5 as it places the National Defence and Security Council above the hluttaw, the Burmese Parliament, with 10 of its 11 members being officers or former officers. ${ }^{6}$ Sein's restructuring has been unmatched by any previous government leadership since the coup d'état of 1962. The latter brought to power a military junta (under the official name of the State Peace and Development Council, SPDC, successively changed into the State Law and Order Restoration Council, SLORC, and again into the SPDC) which ruled the country until 2011. The SLORC/SPDC suppressed domestic dissent and exercised absolute power, despite 20 years of sanctions imposed by the EU and other international actors. The new developments have been acknowledged by the EU as 'historic improvements,' 7 and as 'a significant step towards further democratisation in Myanmar' by the Association of South East Asian Nations (ASEAN). ${ }^{8}$ ASEAN is the regional group of which Myanmar has been a member since 1997. Within ASEAN, the European Union raised its concerns about Myanmar and 'encouraged positive changes.'9

The transformations in Myanmar gave way to a new phase in the relations with the European Union. The European Council suspended the visa ban on cabinet members and other high ranking officials in 2011, and placed Myanmar under the Everything but Arms (EBA) regime. High Representative Ashton opened a EU Office in Yangon, which was later upgraded to a Delegation. The European Union has more than doubled the development aid (to about 150 million euros for 2012-13), explored the feasibility of a bilateral investment agreement, and reinstated the system of generalised tariff preferences with Yangon in mid 2013. It expanded bilateral trade with Myanmar (226.37 million dollars in 2012) as well as Myanmar's exports to the EU (43.54 million dollars) and imports from the EU (182.83 million dollars), ${ }^{10}$ all of which are vital to Myanmar (with a GDP of US\$ 876 in 2010). ${ }^{11}$ It allocated initial funds to the Myanmar Peace Centre in Yangon (EUR 700,000) in 2012, and further contributed EUR 30 million in 2013 to the ethnic peace process. ${ }^{12}$ It has agreed to the building up of a lasting EU-Myanmar partnership. ${ }^{13}$ To turn commitments into reality, a joint Task Force met in Myanmar in November 2013,14 following the first Myanmar-EU Forum in Nay Pyi Taw in

\footnotetext{
4 Council conclusions, 3159th Foreign Affairs Council Meeting, Luxemburg, 23 April 2012. Censorship laws, however, still exist and are enacted; see: T. Myint-U, 'Help Myanmar's peace talks to transform Asia,' Financial Times, 22 November 2013.

5 Myanmar's military (the Tatmadaw) is constitutionally protected and exempted from civilian oversight. Article 20(b) of the Constitution gives the military complete authority over the ministries of defence, interior and border affairs, as it appoints all three ministers. Article 109(b) and 141(b) reserve $25 \%$ of parliamentary seats for the military, which in effect gives them a veto over any attempts to alter the Constitution because of the supermajority required for revision. D. Tonkin, EastAsiaForum, 3 May, 2013.

6 A. MacDonald, EastAsiaForum, $1^{\text {st }}$ May, 2013. <http://www.eastasiaforum.org/2013/o5/o1/the-tatmadaws-newposition-in-myanmar-politics/>, accessed 19 September 2013.

7 Council Conclusions, 23 April 2012.

${ }^{8}$ Chairman's Statement, $20^{\text {th }}$ ASEAN Summit, Phnom Penh, 2012, (paragr. 87). ASEAN is formed by Indonesia, Malaysia, the Philippines, Singapore and Thailand, which are the five founding states, to which later Brunei, Vietnam, Laos, Myanmar and Cambodia also joined, totaling ten members.

9 EEAS Myanmar,<http://eeas.europe.eu/myanmar/index en.htm>, accessed 14 November 2012.

${ }_{10}$ Myanmar, EU agrees to use forum to advance ties. 20 June 2013. <http://www.globaltimes.cn/content/790343. shtml\#.UdrvwpX3AfE >, accessed 19 September 2013.

${ }^{11}$ United Nations, National Accounts Main Aggregates Database, <http://unstats.un.org/>, accessed 19 September 2013.

12 European Commission, IP/12/1167.

13 Joint statement, Brussels, 5 March 2013, EUCO 58/13. <http://www.consilium.europa.eu/uedocs/cms_data /docs/pressdata/en/ec/135830.pdf >, accessed 19 September 2013.

14 <http://europa.eu/rapid/press-release_MEMO-13-176_en.htm> accessed 19 September 2013.
} 
June 2013. The Council has indicated that, having imposed sanctions calling for a change, it now feels a responsibility to help, and assist the government in rebuilding its place in the international community. 15 These developments offer an opportunity to review the EU's efforts to induce Myanmar's military regime to work towards political transformation. These developments raise the question: what are the elements of continuity and change in EU behaviour within its interaction with ASEAN with regard to Myanmar? As the EU has used the ASEAN framework to raise and discuss its concerns about Myanmar, the Association's behaviour also comes into focus.

This is an empirical investigation hinging on the evolution of the EU in world affairs via its political ties to ASEAN. The EU's concern that the Myanmar issue not destabilise its relations with ASEAN has remained constant. Changes have been identified as forming three different phases: 1991-1997, 1998-2006 and 2007-2012. The aspiration to escape from pervasive China ${ }^{16}$ and the desirability of new partners were crucial factors in the realisation of these changes. Official documents from the EU, the European Commission, and European Council Conclusions and Common Positions, speeches and declarations issued at ASEAN, Asia-Europe and other meetings, together with Southeast Asian and European newspapers, secondary sources and interviews conducted in Myanmar in January 2013, including one with a former EU Special Envoy for Myanmar and ASEAN leaders, contribute to this work. Many scholars have hinted at the extent to which the issue of Myanmar has caused problems to the EU-ASEAN links, but no emphasis has been made of the extent to which the Myanmar case has conversely helped to reinforce the long-lasting EU-ASEAN relationship; that is the focus of this article.

\section{Official Documents and Recent Publications}

How can we explore the European Union's attention to Myanmar through its connections with ASEAN (the Asia-Europe Meeting (ASEM) is an offshoot of ASEAN), ${ }^{17}$ and have similar investigations already been conducted? The analytical approach employed in this article builds upon official documents both by the EU and the European Commission that envision the EU's strategy towards Southeast Asia. The ASEAN group is a central element, and Myanmar is connected by the EU discourse to ASEAN when it appears in the documents, which include: the 1994 Communication of the Commission to the Council 'Towards A New Asia Strategy;' 18 the 2001 Commission Communication on 'Europe and Asia: A Strategic Framework for Enhanced Partnerships;'19 the 2003 Communication from the Commission 'A new partnership with South East Asia;'20 the 2007 European Commission's 'Country Strategy Paper on Myanmar;'21 and the 2013 'Comprehensive Framework for the European Union's policy and support to Myanmar/Burma.'22 As the Commission explains (1994), the term 'Asia' includes three sub-regions, one of which is Southeast Asia.

\footnotetext{
15 Council conclusions on the Comprehensive Framework for the European Union's policy and support to Myanmar/Burma, Foreign Affairs Council meeting, Brussels, 22 July 2013.

${ }^{16}$ Hatred for India is also an issue within Myanmar.

${ }_{17}$ Asia-Europe Meeting is considered an emanation of the Association because negotiations for the first ASEM summit were carried out through the interregional dialogue channel between ASEAN and the EU (Yeo 2013, 332). ASEM reflected ASEAN's ambition to promote an East Asian regionalism around the ASEAN core (Manea 2013, 321-2). L. Yeo, 'The AsiaEurope Meeting' in T. Christiansen, E. Kirchener and P. Murray, (eds) The Palgrave Handbook of EU-Asia, Houndmills, Palgrave, 2013, pp. 330-343. M. G. Manea, 'The Institutional Dimension of EU-ASEAN Plus Three Inter-regional Relations,' in Christiansen et al (eds), op. cit., pp. 313-329.

18 COM(94)314, Brussels, 13 July 1994.

$19 \operatorname{COM}(2001) 469$, Brussels 4 September 2001.

${ }^{20} \operatorname{COM}(2003) 399$, Brussels, 9 July 2003.

${ }^{21}$ The EC/Burma/Myanmar Strategy Paper (2007-2013).

22 Council conclusions, 22 July 2013. 
These documents support the following strategic setting concerning the EU: the establishment of an important presence in Southeast Asia is claimed to allow the European Union to ensure that its interests (in economic and security matters - arms control, nonproliferation and the security of the sea lanes) are fully acknowledged in this key region. ${ }^{23}$ The EU's intention to raise its political and economic presence across the region to a level commensurate with the growing global weight of an enlarged EU is another claim, to which the key priority of further strengthening the long-standing partnership with ASEAN contributes. ${ }^{24}$ The account that economic imperatives for closer cooperation are based on the fact that Southeast Asia is set to become one of the most dynamic growth areas in the world economy has supported the EU's proposition to revitalise its relations with ASEAN. 25 The 2007 document discloses that EU Ministers were ready to discuss Burmese matters with their Myanmar counterparts at several regional meetings (ASEAN-EU Ministerial, ASEM, or bilaterally at the margins of these meetings). ${ }^{26}$ And finally, the 2013 document shows that the EU's goals include assisting Myanmar's government in reestablish its place in the international community and helping it to reap the benefits of its integration into ASEAN. ${ }^{27}$ These discourses of the EU frame the observation of the European Union's behaviour within EU-ASEAN's interactions with regard to Myanmar, and will later serve to assess the EU's behaviour over the period considered.

\section{Recent publications}

An examination of the literature in this field reveals that some researchers have considered the EU's relationship to Myanmar, explained how the EU has jeopardised its relations with ASEAN through its criticism of that country, ${ }^{28}$ and provided suggestions about how the EU might support reform in Myanmar. ${ }^{29}$ An overview of recent developments there, 30 and a focus on the reforms have also been provided. ${ }^{31}$ The issue of whether the EU's sanctions induce undemocratic governments to change their ruling system formed the topic of a case study on Myanmar. ${ }^{2}$ Another recent contribution reviewed the comprehensive ties between the EU and ASEAN, paying brief attention to Myanmar as a permanent point of contention. 33 Research on how interaction is central to analysing human rights, as part of the process of ASEAN's identity formation, has also been published, shedding some light on the diplomatic incidents and tensions that arose when the EU embarked on a region-to-region interaction with Myanmar.34 The argument that the EU's targeted (rather than full) sanctions allowed the EU member states to protect their commercial and/or political interests in Myanmar

\footnotetext{
${ }_{23} \operatorname{COM}(94) 314$, op. cit., pp. 2-3.

${ }_{24} \operatorname{COM}(2003) 399$, op. cit., pp. 3, 22.

${ }_{25} \operatorname{COM}(2003) 399$, op. cit., p. 3 .

${ }^{26}$ The EC/Burma/Myanmar Strategy Paper (2007-2013), op. cit., p. 20.

27 Council conclusions, 22 July 2013, op. cit., pp. 2, 4.

${ }^{28}$ S.B. duRocher, 'The European Union, Burma/Myanmar and ASEAN: A challenge to European norms and values or a new opportunity?,' Asia Europe Journal, Vol. 10, Nos. 2-3, 2012, pp. 165-180.

29 J. Parello-Plesner, 'How the EU can support Reform in Burma', European Council on Foreign Relations, 2012 , pp. 1-9. <http://www.ecfr.eu/content/entry/how_the_eu_can_support_reform_in_burma>, accessed 19 September 2013.

${ }^{30}$ L. Rieffel, Myanmar on the Move: An Overview of Recent Developments,' Journal of Current Southeast Asian Affairs, Vol. 31, No. 4, 2012, pp. 31-49.

${ }^{31}$ M. Bunte and C. Portela, 'Myanmar: The Beginning of Reform and the End of Sanctions,' policy brief, GIGA Focus International, No. 3, German Institute for Global and Area Studies: Hamburg, June, 2012.

${ }^{2}$ C. Portela, European Union Sanctions and Foreign Policy. When and why do they work? London, Routledge, $2010 ;$ C. P. Portela, P. Vennesson, 'Sanctions and Embargoes in EU-Asia Relations' in Christiansen et al (eds), 2013, pp. 198-210.

33 G. Brettner-Messler,'EU and ASEAN - The Interregional Relationship between Europe and Asia', in Gareis, SB., G. Hauser and F. Kernic, (eds) The European Union: A Global Actor?, Opladen/Farmington Hills, Budrich Publishers, 2012, pp. 138-16o.

34 M. Manea, 'How and Why Interaction Matters: ASEAN Regional Identity and Human Rights,' Cooperation and Conflict, Vol. 44, No. 1, 2009, pp. 27-49.
} 
was also sustained (p. 158).35 An evaluation of ASEM in its first decade (including both how it has been considered as the way out of the EU-ASEAN deadlock on Myanmar and how it has been challenged by the crisis) was made available. ${ }^{6}$ The issue of Myanmar's inclusion in the 2004 ASEM enlargement has been explored.37 An investigation of EU-ASEAN ties with attention to values, norms and culture, and also to Myanmar is accessible. ${ }^{8}$ The view that ASEAN's intra-regional and inter-regional human rights interactions with Europe are mutually dependent was discussed with ample reference to Myanmar.39 The argument of how the EU-ASEAN relationship may turn out to be not only rich in declarations but also of a substantial character has been considered, though Myanmar was dealt with only briefly. 40 The lessons that the EU offers for Myanmar's ASEAN chairmanship in 2014 are also available together with the EU views on the 2015 elections. ${ }^{41}$

Other publications have centred on EU ASEAN links, or on ASEM, but not all of them have paid attention to Myanmar. The lessons that the EU could learn from ASEAN have been explained, ${ }^{42}$ and the EU's limited strategic approach to Asia criticised. 43 Reflections on different aspects of EU-Asia relations were included in a handbook, 44 and a selection of topics from an interdisciplinary perspective concerning these relations was made available. 45 Further studies sought to shed light on the importance of ASEM from a European perspective, 46 and examined the EU's foreign policy in the Asia Pacific region. $47 \mathrm{~A}$ less recent work explored the EU in Southeast Asia together with its ties to ASEAN.48 While Casarini made no reference to Myanmar, Zhou and Forster did so only indirectly.

Other analysts have studied Sino-Myanmar relations explained how China emerged as the most important foreign actor in Myanmar after the Western boycott of its industrial and agricultural sectors 49 and examined how a series of events, since mid-2011, including the rapid improvement of Myanmar's relationship with the West, have 'frustrated' China's aspiration to engage in a 'loyal friend' partnership with Myanmar. $5^{\circ}$ Other observers have

35 K. Smith, 'The Limits of Proactive Cosmopolitanism: The EU and Burma/Myanmar, Cuba and Zimbabwe,' in Elgstrom, O. Smith, M. (eds) The European Union's Roles in International Politics. Concepts and Analysis, London, Routledge, 2006.

36 'ASEM in its Tenth Year: Looking Back, Looking Forward,' European Background Study, University of Helsinki, 2006.

37 E. Fitriani, 'ASEM and Southeast Asian countries' foreign policy. Study case: The issue of Myanmar in the 2004 ASEM enlargement,' ISEAS Singapore, forthcoming, pp.1-37.

${ }^{38}$ N. A. deFlers, 'EU-ASEAN Relations: The Importance of Values, Norms and Culture', Working Paper No. 1, EU Centre in Singapore, 2010.

39 M. Manea, 'Human rights and the interregional dialogue between Asia and Europe: ASEAN-EU relations and ASEM,' The Pacific Review, Vol. 21, No. 3, 2008, pp. 369-396.

40 J. Moeller, 'ASEAN's Relations with the European Union: Obstacles and Opportunities,' Contemporary Southeast Asia, Vol. 29, No 3, 2007, pp.465-482.

41 L. Marchi, 'Myanmar's ASEAN challenges,' New Mandala, Australian National University, 2014, <http://asiapacific.anu.edu.au/newmandala/2014/05/13/myanmars-asean-challenges/>, accessed 13 May 2014.

$4^{2} \mathrm{~K}$. Mahbubani,'Can the EU learn lessons from ASEAN?,' 2012, <http://www.mahbubani.net/articles\%20by\%20dean /can-the-eu-learn-lessons-from-asean.pdf>, accessed December 2012.

43 K. Engelbrek, 'The Missing Link in the EU's Nascent Strategic Approach toward Asia: Military Diplomacy,' Asia-Pacific Review, Vol. 19, No. 2, 2012.

44 Christiansen et al. (eds) op. cit.

45 D. Novotny and C. Portela (eds) EU-ASEAN Relations in the $21^{\text {st }}$ Century. Strategic Partnership in the Making, New York, Palgrave, 2012.

${ }^{46}$ W. Zhou, 'Beyond A Trade Agenda: EU's Interregional Approach Towards East Asia', European Foreign Affairs Review, Vol 16, 2011, pp. 407-426.

47 N. Casarini, 'EU Foreign Policy in the Asia Pacific: Striking the Right Balance Between the US, China and ASEAN,' EUISS, 2012, pp. 1-6.

${ }^{48}$ A. Forster, 'The European Union in South-East Asia: continuity and change in turbulent times,' International Affairs, Vol. 75, No. 4, 1999, pp. 743-758.

49 N. Swanstrom, 'Sino-Myanmar Relations: Security and Beyond', Institute for Security and Development Policy, Stockholm, 2012, pp.1-25.

50 Y. Sun, 'China's Strategic Misjudgment on Myanmar,' Journal of Current Southeast Asian Affairs, Vol. 1, 2012, pp. 7396. 
focused on the potential sources of instability that Myanmar faces in its surrounding region, which could threaten its neighbours, including China. ${ }^{1} \mathrm{~A}$ further work centred on Myanmar's President Sein's priorities and civil society's role in representing the popular interests, 52 while yet another analysed the problem of democracy in Myanmar. 53 Explanations of how the recent political changes in Myanmar came about, 54 and how peace prospects may evolve, with a strong emphasis on human right claims, have also been offered,55 together with an exploration of the major trends in Foreign Direct Investment in Myanmar (1989-2011).56 A brief hint at Myanmar in its geopolitical complexity considered in the security regionalism of the Asia-Pacific area was proposed. 57 The argument that ASEAN's failure to take a stronger line on Myanmar has less to do with its non-interference norms than with the interests of the region's illiberal elites has been sustained. ${ }^{8}$ An analysis of how different socio-economic interests shape foreign policy in the ASEAN states is accessible, with a focus on the ASEAN Inter-Parliamentary Myanmar Caucus. 59 A recent extensive examination of all of the developments which have characterised Myanmar over the years, including its participation in ASEAN, is now available. ${ }^{60}$ Less recent, but equally important, analyses have focused on the complex relations between Myanmar and ASEAN, ${ }^{61}$ together with the discussion of Myanmar's foreign policy goals before 2007.62 Also, the way in which ASEAN might have affected political change in Myanmar has been the subject of study, 63 as well as ASEAN's diplomatic and security culture with regard to Myanmar. ${ }^{64}$ Yet, none of these works made any mention at all of the European Union.

It is true, therefore, that Myanmar has become the focus of increasing attention among scholars and observers alike. However, an observation of the evolution of EU behaviour within EU-ASEAN's interactions with regard to Myanmar (through the reading of EU, ASEAN and ASEM official documents) in order to shed light on continuity in the EU's as well as on changes in the EU's and ASEAN's conduct, as this article seeks to undertake, is not yet available. The present article intends to contribute to filling this gap.

\section{The Three Distinct Phases in Action}

\footnotetext{
${ }^{51}$ J. Kurlantzick, 'Myanmar: Sources of Instability and Potential for US-China Cooperation,' Council on Foreign Relations. ${ }^{2}$ M. Thuzar, 'Myanmar: No Turning Back,' Southeast Asian Affairs, Vol.1, 2012, pp.203-219.

53 D. Steinberg, 'The Problem of Democracy in the Republic of the Union of Myanmar: Neither Nation-State Nor StateNation?' Southeast Asian Affairs, Vol.1, pp. 220-237.

54 K. Hlaing, 'Understanding Recent Political Changes in Myanmar', Contemporary Southeast Asia, Vol. 34, No. 2, 2012, pp. 197-216.

55 A. South, 'The Politics of Protection in Burma. Beyond the Humanitarian Mainstream,' Critical Asian Studies, Vol. 44, No. 2, pp. 175-204. T. Kramer, 'Ending 50 years of military rule? Prospects for peace, democracy and development in Burma', NOREF Report, Norwegian Peacebuilding Resource Centre, 2012, pp. 1-14.

${ }^{5} 6$ J. Bissinger, 'Foreign Investment in Myanmar: A Resource Boom but a Development Bust?' Contemporary Southeast Asia, Vol. 34, No. 1, 2012, pp. 23-52.

57 C. Hughes, 'New Security Dynamics in the Asia-Pacific: Extending Regionalism from Southeast to Northeast Asia,' The International Spectator, Vol. 42, No. 3, 2007, pp. 319-335.

${ }^{8}$ L. Jones, 'ASEAN's Albatross: ASEAN’s Burma's Policy, from Constructive Engagement to Critical Disengagement,' Asian Security, Vol. 4, No. 3, 2008, pp. 271-293.

59 L. Jones, 'Democratization and foreign policy in Southeast Asia: the case of the ASEAN Inter-Parliamentary Myanmar Caucus', Cambridge Review of International Affairs, Vol. 22, No. 3, 2009, pp. 387-406.

${ }^{60}$ J. Haacke, 'Myanmar: now a site for Sino-US Geopolitical Competition?', LSE IDEAS, 2012; J. Haacke, 'The Myanmar imbroglio and ASEAN: heading towards the 2010 elections,' International Affairs, Vol. 86, No. 1,2010, pp. 153-174.

61 J. Haacke, 'Myanmar and ASEAN' The Adelphi Papers, Vol 46, No. 381,2007a, pp. 41-60.

62 J. Haacke, 'The Political-Security Imperative and Foreign Policy Goals', The Adelphi Papers, Vol. 46, No. 381,2007b, pp. $13-24$.

63 J. Haacke, 'ASEAN and Political Change in Myanmar: Towards a Regional Initiative?' Contemporary Southeast Asia, Vol.30, No. 3, 2008, pp. 351-378.

64 J. Haacke, "Enhanced Interaction" with Myanmar and the Project of a Security Community: Is ASEAN Refining or Breaking with its Diplomatic and Security Culture?' Contemporary Southeast Asia, Vol. 27, No. 2, 2005, pp. $188-216$.
} 
How did the European Union interact with ASEAN regarding Myanmar? The policy of dialogue between the European Community (EC) and ASEAN (which established itself as a regional group in 1967) developed due to trade and economic interests. Inter-regional relations were formalized in 1977, and the first official connections were based on the ASEAN-EC Cooperation Agreement of 1980. This agreement incorporated the areas of commerce, economy and development. The procedures for the EU ASEAN dialogue consisted of an annual meeting of foreign ministers, and additional special meetings as required.

\section{Different approaches}

The two regional groups adopted distinct approaches to Myanmar. More generally, the European Union was inclined to enhance its 'global role' and extend its influence to Asia and Southeast Asia. With the entering into force of the Maastricht Treaty in 1993, along with the changes that this introduced in institutional and political terms, the EU embraced an 'allinclusive policy' in external relations, incorporating a variety of issues. This comprehensive policy particularly focused on the consolidation of democracy, sustainable development and good governance. The beliefs in freedom from fear, respect for the rule of law, human rights and fundamental freedoms, freedom from want, and social wellbeing in all of its aspects lay at the basis of the 'good governance' of the European Union. These values would later, in 2003, be included in the European Security Strategy. The EU's interpretation of 'global security' respected the principle that all states needed sufficient access to the above 'goods.' 65 This approach was to apply also to Myanmar. 66

For ASEAN, the compliance with the non-interference norm to its members' conduct of internal affairs was one of the principles it held, as a signatory of the 1976 Treaty of Amity and Cooperation (TAC). The ASEAN members placed great emphasis on the belief in 'mutual respect for independence, sovereignty and territorial integrity and national identity.' They declared loyalty to the principles of the United Nations Charter, and adherence to 'justice and the rule of law' as ideals to defend when they undersigned the Bangkok Declaration of 1967, constitutive of their group. ASEAN had not interpreted the political repression in Myanmar as an issue of democratic rights, as had the EU. Repression was an internal problem that could eventually be dealt with bilaterally. ASEAN developed a 'quiet' and informal style of diplomacy to Myanmar that showed respect, tolerance for diversity and a commitment to non-criticism of the junta. ${ }^{67}$

The European Union engaged in a sanction strategy through its own channel of the Common Foreign and Security Policy (CFSP) (which was introduced by the Maastricht Treaty and reinforced by the Amsterdam and Nice Treaties in 1999 and 2001). ${ }^{68}$ The EU sanctions are understood here as measures taken in reply to Myanmar's junta behaviour, which the EU maintained was contrary to international law. ${ }^{69}$ They are considered part of the bargaining process, stressing that the ability to reciprocate concessions made by the targeted state was essential for success. They are not intended to be repressive or punitive but, rather, coercive measures. The CFSP common positions were supported by the unanimity requirement of

\footnotetext{
${ }^{65}$ S. Biscop, 'From Reflections to Power: Implementing the European Security Strategy,' in G. Hauser and F. Kernic (eds), European Security in Transition, Aldershot, Ashgate, 2006, pp. 87-102.

${ }^{66}$ See: G. Wiessala, Re-orienting the Fundamentals: Human Rights and New Connections in EU-Asia Relations, Burlington, Ashgate, 2006.

${ }^{67}$ See: Hughes op cit, pp. 321-2.

${ }^{68}$ With the reforms of the Lisbon Treaty (2010), the CFSP has become an integral part of the Common Security and Defence Policy.

69 Taken by Combacau, pp. 313-4 in Portela, op cit, p. 19; p.21 and adapted by the author to the European Union. 
the Council. The CFSP provisions were supervised by the Council, which regularly reported to the Presidency and the European Commission, in order to review the decisions adopted in the light of new developments in Myanmar. When needed, further measures were deliberated, and, in the case of improvements, the suspension of particular restrictions was considered as well as the gradual resumption of cooperation, as reported in the Council Common Position (CCP) (96/635/CFSP) of 28 October 1996. These developments however occurred over a long period and in fact the sanctions against Myanmar were renewed over several years. 70

ASEAN's line of opposition to the discourse of the EU on good governance (and democratic issues) grew steadily. Paradoxically the balance of preferences within the Asian group was inclined to favour states, which were governed by authoritarian regimes. The latter were keen to exclude attempts to enter into an intra-regional debate on governance and humanitarian themes. Yet there were exceptions, such as ASEAN states developing national, liberal-democratic, political frameworks (Philippines and Thailand), and non-state actors engaged in different fields of social activism. Notwithstanding this intra-regional debate's fragmentation, the rejection of the 'external other'71 was the common pattern uniting both the supporters of democracy and authoritarianism. In its relations with the EU concerning Myanmar, the Association defended its opposition to 'external interferences' (and to the good governance line). Hence, as the EU insisted on sanctions, ASEAN rejected censure of the regime by its EU dialogue partner, as it has been observed throughout the 1991-1997 period. Later, in the 1998-2006 period, the EU moderated its criticism of Myanmar, while the Association appeared to distance itself from rejecting censure of the regime by its EU dialogue, and subsequently, throughout the 2007-2012 period, the EU employed targeted sanctions and limited development cooperation, while ASEAN encouraged better governance. The respective developments characterising these three phases will now be explored.

\section{The 1991-1997 years}

The European Union's pressure for change on the military regime built up in the aftermath of the junta's violent response to the Burmese pro-democracy demonstrations in 1988. However, only in 1991 did the EU act officially and collectively with sanctions prompted by the junta's failure to recognise the results of the May 1990 elections. These earned Suu Kyi's National League for Democracy 59 per cent of the votes, and would have guaranteed 80 per cent of the parliament seats. Suu Kyi had been under house arrest since 1989. According to the Council, the EU was disappointed at the unwillingness of SLORC, the military junta, to enter into a meaningful dialogue with it, and reaffirmed its determination to resume such dialogue at some point in the future. The Council agreed to the suspension of development aid (excluding humanitarian aid programmes) and on the establishment of diplomatic sanctions. ${ }^{22}$ Sanctions embargoed weapons and their ammunition and the maintenance and transfer of military technology. At the meetings with ASEAN, the EU 'expressed its overall interest in democracy (and human rights'), raising the irritation of the Association's members (in Kuala Lumpur in 1990, Luxemburg in 1991, and Manila in 1992), while ASEAN maintained its critical stance towards the European Union when communicating with it. However, in 1994, the Foreign Ministers of the two regional groups agreed on a joint

\footnotetext{
70 Intensification of sanctions is documented by Portela, op cit, (2010) and Manea, 'How and Why Interaction Matters: ASEAN Regional Identity and Human Rights,' op cit. ASEAN states' attitude to sanctions is documented by Haacke, The Myanmar imbroglio and ASEAN: heading towards the 2010 elections, op cit.

${ }^{71}$ Manea, 'How and Why Interaction Matters: ASEAN Regional Identity and Human Rights,' op cit, p. 35 ; p. 45.

72 Press 91/238, 29 July 1991.
} 
Declaration in Karlsruhe within which they 'expressed the hope that ASEAN's policy of constructive engagement and the EU's willingness to engage in a critical dialogue will eventually contribute to achieving more sustainable improvements in all fields' (paragraph 34). ASEAN's policy of constructive engagement indicated 'a mix of moderate diplomacy and greater economic interaction' which was respectful of the non-interference ideology.73 The Commission's Communication of 1994, 'Towards a New Asia Strategy', began with the statement that the 'rise of Asia [was] dramatically changing the world balance of economic power' (p. 1). As a strategy, the EU aimed to remain included in the Southeast Asian region. The controversy over Myanmar was in some way watered down, as it arose in Karlsruhe, and relations tended to focus on economic ties. 74

The 1996 Council's request for the unconditional release of political prisoners and introduction of additional sanctions were motivated by the junta's further repressive behaviour. 75 With the EU's policy in Southeast Asia focusing on respect for democratic principles and associated themes (which 'together form[ed] a major objective of the external policy of the European Union' - p. 12), ${ }^{6}$ Myanmar increasingly became the centre of attention of EU-ASEAN affairs. The argument of diversity of vision took broader shape that same year, 1996, when the Association's heads of state granted observer status to Myanmar within ASEAN.

\section{The 1997 crisis: Myanmar's admission to ASEAN}

The Association's enlargement77 led its respective new members to join the 1980 EC-ASEAN Cooperation Agreement. By contrast, Myanmar 'was excluded ... because of its lack of democracy and its poor human rights record.' 78 The EU-ASEAN meetings were cancelled in winter 1997. The EU protracted its previous sanctions for a further six months. 79 Sanctions were mostly directed at the industrial and agricultural areas as a response to the use of forced labour. The measures also involved the withdrawal of Myanmar's access to the system of generalized tariff preferences. The Council declared that, having discussed the implications of Myanmar's admittance to ASEAN, it expected such a membership to contribute to the promotion of democratic principles. The European Union had some difficulty in coping with Myanmar's accession. The EU was a human rights advocate, as well as accountable to the national parliaments and the European Parliament, and, furthermore, it was constrained by the unanimity principle on which EU's foreign policy formulation was based. ASEAN had no strict criteria for membership and had 'never made it conditional to political reform.' ${ }^{\circ}$ With the Association's inclusion of Myanmar together with Cambodia and Laos, and previously (in 1995) of Vietnam, ASEAN was becoming more representative of the region. The European Union had more reason than ever to confirm its intention 'to raise the profile of Europe' in Southeast Asia (p. 4), ${ }^{81}$ and was even inclined to take a pragmatic course, putting aside sensitive issues.

\section{Continuing the dialogue?}

\footnotetext{
73 Haacke, 'Myanmar and ASEAN,' op cit, p. 42.

74 ASEAN and EU's interactions on political matters grew when the ASEAN Regional Forum (ARF) was launched in 1993.

75 CCP (96/635/CFSP), 28 October 1996.

${ }^{76} \mathrm{COM}(94) 314,1994$.

77 Enlargement included Vietnam in 1995 and Cambodia and Laos in 1997.

${ }^{78}$ Fact Sheets on the European Union, 2012, <http://www.europarl.europa.eu/ftu/pdf/en/FTU_6.4.12.pdf>

$792019^{\text {th }}$ Council Meeting - General Affairs - Luxembourg, 26 June 1997.

80 X. Nuttin, 'EU-ASEAN Relations in the $21^{\text {st }}$ Century,' in Novotny et al (eds), op cit, p.175.

${ }^{81} \mathrm{COM}(94) 314$. 
In 1996, during the EU-ASEAN political crisis, Singapore's Prime Minister (Goh Chok Tong) proposed the Asia-Europe Meeting. ${ }^{82}$ ASEM would allow the parties to resume the dialogue for at least three reasons. First, ASEM (which included 15 EU member states, the European Commission's President and the ASEAN members) had the advantage of accepting also China, Japan and South Korea, and allowed for the incorporation of India and Pakistan. Second, the participating states were to meet bi-annually. This configured a looser structure than the procedures for the EU ASEAN dialogue. In the years in-between the summits, foreign ministers held their meetings. The novelty of ASEM's role lay also in its capacity to also offer a forum for the presentation of viewpoints, as a kind of preparation for the later discussions at the appropriate summits. ${ }^{8}$ Third, the process was very informal. The instruments for implementing the collective agreements were the (economic and political) protocols. Protocols implied simple procedures if compared to the Cooperation Agreements which needed the European Parliament's authorisation. For the European Union, ASEM constituted a new structure and a new approach. Few choices were available to the EU in its attempt to continue the dialogue with the Southeast Asian states, and the Union welcomed the ASEM process. ${ }^{84}$ Yet, the EU's continued use of coercion towards Myanmar was expressed in the Council's declaration that its membership of ASEAN did 'not automatically imply membership of ASEM', 85 a position that created further controversy. Rejecting censure of Myanmar's regime from its EU dialogue partner, in none of ASEM's conclusive official documents did ASEAN make explicit reference to Myanmar or to the situation there. ${ }^{86}$

\section{Burmese perceptions on sanctions and beyond}

What are the perceptions of the European Union and its policy among the people in Myanmar? Burmese perspectives on the EU and its action are hard to qualify. Some among civil society in recent interviews have stated that they have no idea what the European Union is, while others preferred to ignore it, taking the view that the Burmese people have not been helped but penalised. Myanmar's development has been curbed: 'how could we have a positive conception of the EU?' If there was an idea of restraining the junta from acquiring arms, time had been lost due to the embargo because the SLORC/SPDC had obtained weapons through Singapore, China and Russia, to mention only a few providers. ${ }^{87}$ A 'wellinformed' Burmese citizen dismissed sanctions. The military in power turned the circumstance of being countered by external forces to its advantage. Domestically, the junta defied the situation, and strengthened the significance of the principle of non-interference in Myanmar's affairs, reinforcing the argument that Myanmar's sovereignty was a value to be respected. 88 A similar judgment concerning sanctions upheld that the SPDC was disturbed, but not to the extent intended by the sanctions. 'Restrictive actions' built up the junta's attention to privilege its neighbourhood, and at the same time secured its protection within the region. ${ }^{89}$ On the extent of the preoccupation with economic restraint, some responses indicated that it was true that poverty had increased nationwide and that the local industries had been weakened. There was no alternative but to accept this and, anyway, people knew that the country was rich in natural resources. The extraction sector was trading well, particularly through Thailand. These resources would have been further exploited in

\footnotetext{
82 ASEM was conceived by Singapore and France in 1994.

83 Brettner-Messler, op cit, p.145.

84 Forster, op cit, pp. 752-754.

85 Council Meeting, 26 June 1997.

86 ASEM1, Bangkok, 1996; ASEM2, London 1998.

87 Interview with a Burmese academic, Yangon, January 2013.

88 Interviews with members of civil society, Myanmar Book Centre, Yangon, January 2013

${ }^{89}$ Interview with a South Korean diplomat, Yangon, January 2013.
} 
future and people believed that a better future existed.90 Others insisted that the hardship (i.e. sanctions) created by the EU for the junta had no support in the region. At times, there had been (political) adversity to overcome with certain states, but some other countries were very supportive and helped to maintain balanced relations. The junta also operated in the region's interest (i.e. ASEAN), not over-reacting to criticism when this occurred. The SPDC has understood that the neighbouring countries were under intense international pressure, which was negatively affecting their project of deepening integration. ${ }^{91}$ Not everybody in Myanmar supported Su Kyi. There was some indifference if not opposition against the NLD's leader. One of the areas where such attitudes were unveiled was the region around Pathein in Mon State, which has been severely hit by Cyclone Nargis, in May 2008, during which 140,000 died.92 With regard to Myanmar's unexpected turn to the West, the interviews with Burmese people and ASEAN leaders suggested that it was not the constrictions imposed by the Union (and by other international actors) but rather the reality of the hatred for China within Myanmar that proved the driving force. China exploited many natural resources and abused the conditions of poverty and underdevelopment. Irritation at the encroaching role played by China in Myanmar and the desirability of new partners contributed to make the impetus for change and reform. 93

\section{EU behaviour and statements}

What does the observation of EU behaviour within the EU-ASEAN interaction convey with regard to Myanmar? During its 1997 rupture with ASEAN over the Burmese accession, the European Union issued a declaration intended to soothe the crisis: 'The EU looks forward to continued close cooperation between our two respective regions [and] ... would like ... to re-affirm its commitment to the EU-ASEAN dialogue.'94 More evidence emerged due to the EU's attitude to the Asia-Europe Meeting's new framework of resuming the dead consultations. In a Commission document, in 2001, the appeal of ASEM was put into focus: 'The value of the ASEM process will be further enhanced through a broader participation.'95 The EU appears keen to avoid the Myanmar issue destabilising its relations with ASEAN. An additional element has also emerged. Previously, in 1997, after firmly countering Yangon's association, the EU not only accepted but also stated that 'the Council agreed that the opportunity of the EU-ASEAN dialogue should be used to discuss the situation in Burma/Myanmar' (p. 8). ${ }^{6}$ Hence the Council emphasised the welcoming occasion to reinforce the dialogue with the Southeast Asian countries via this new commitment regarding Myanmar. This is a new position describing the EU-ASEAN relationship vis-à-vis Myanmar.

\section{From 1998 to 2006}

In the aftermath of the problems arising from the 1997 dialogue, a combination of external influences and domestic dynamics contributed towards changing both the EU and ASEAN's attitude towards Myanmar. Firstly, as early as 1994, the EU had expressed an intention 'to accord Asia a higher priority than [was] at present the case', an objective that remained valid.

\footnotetext{
90 Interview with an officer of a governmental agency, Nyaungshwe, Shan State, January 2013.

${ }^{91}$ Interview with an academic, Myanmar Book Centre, Yangon, January 2013.

$9^{2}$ Interview with a member of the NLD near Pathein in Mon State, January 2013.

93 Interviews with Burmese people, British Council, Yangon centre, January 2013, and with ASEAN leaders, Macau, May 2013.

94 8637/97 (Presse 189) E/59/97.

$95 \operatorname{COM}(2001) 469$.

96 Council Meeting, 26 June 1997.
} 
An important component of the EU's position was the pursuit of 'new proactive strategies towards Asia.' 97 These aspects reconfirmed the EU's positive stance on ASEAN, and militated against a rigid approach to Myanmar within the Association. The new position resulted in the Council attempting to start using the suspension of sanctions (April 2003) as a way to obtain compliance, 98 developing a two-pronged strategy by employing both positive and negative actions. Secondly, the Asian financial crisis of 1997-98 led ASEAN members to question the ability of their group to provide a solution to several problems, throwing the Association's collective identity in disarray. 99 Indonesia, and particularly Thailand and the Philippines increasingly criticised ASEAN's practice of refraining from interference, and called for a policy of 'flexible engagement.' The latter intended to allow ASEAN to address the regional crisis caused by the domestic situation. The de-legitimisation of the argument of 'good government without democracy,' which was central to ASEAN's policy, contributed to the fall of the Suharto regime in Indonesia in 1998 and also to its democratisation. These developments forced a revision of the non-interference dogma, and also restructured the field of the human rights discourse among ASEAN countries. Hence, democratic and humanitarian issues' interactions became possible also between ASEAN and the EU. The Association's reaction to the consequences of the economic crisis supported a new input on integration (ASEAN vision 2020 issued in 1997, Hanoi Plan of Action in 1998). Thirdly, some understanding between the EU and ASEAN on Myanmar intended to induce the SPDC to temper its repressive behaviour towards the NLD and its followers, and accept the constitution of a EU Troika to assess improvements in the country in this regard. To balance this concession, the EU was to lessen its inflexible policy on the SPDC. All of these developments encouraged both the EU to tone down its criticism of Myanmar and ASEAN to distance itself from rejecting censure of the regime by its EU partner. ${ }^{100}$

\section{Changes in action?}

Signs of the EU's weakening criticism of Myanmar were provided by the opening of a Burmese diplomatic representation in Brussels around the year 2000, and by the Council introduction of several measures on democratisation assistance. At the same time, the Council reinstated sanctions. ${ }^{101}$ Also, ASEAN modified its language at ASEM3, in Seoul in 2000 in the Chairman's Statement. Myanmar was not cited, but problems similar to those in Myanmar were mentioned. Again, no particular indication concerning that country was given by ASEAN in Copenhagen, in 2002 (ASEM4). In April 2003, the EU tried to suspend sanctions until October, and pledged to refrain from re-imposing the measures if 'substantive progress towards national reconciliation, [together with] the restoration of democratic order' had been made by then. ${ }^{102}$ Shortly afterwards, a new confrontation (the Depayin incident) played against the EU's opening, and the Council negated the suspension before the announced deadline. ${ }^{103}$

\section{Confirming the changes: The Depayin incident and beyond}

\footnotetext{
$97 \operatorname{COM}(94) 314,1994$, op. cit., pp. 4, 17.

98 Portela, op cit, p.82.

99 A. Jetschke, 'Regional Integration Support by the EU in Asia' in Christiansen et al, 2013, p. 233.

${ }^{100}$ Manea, 'Human rights and the interregional dialogue between Asia and Europe: ASEAN-EU relations and ASEM,' op cit, p. 386; p. 391; Manea, 'How and Why Interaction Matters: ASEAN Regional Identity and Human Rights,' op cit, p. 39. ${ }^{101}$ CCPs (2000/346/CFSP), (2001/757/CFSP) and (2002/831/CFSP).

102 CCP (2003/297/CFSP).

103 CCP (2003/345/CFSP).
} 
An attitudinal change among the Association towards the military junta was induced by the events of 30 May 2003, in particular the attack on the supporters of the opposition leader and Suu Kyi's reinstated house arrest. The Association was now openly speaking out about transition in Myanmar in the Joint Communiqué of ASEAN ministers of June 2003, delivered in Phnom Pen. 'Democracy' was a new word which entered the Association's official documents. The junta's domestic conduct and particularly the treatment of Suu Kyi now became an 'issue' in ASEAN's relations with Myanmar. The attitudinal change was confirmed by ASEAN's members, notably by Malaysia's Prime Minister who argued that Myanmar should be expelled from ASEAN if it 'did not release Suu Kyi and another 1,400 political prisoners.' 104 Very distinctively, the Thai Prime Minister 'offered to mediate' between the junta and the broader regional and international community, and discuss a 'roadmap toward democracy' by bringing together all of the countries concerned.105 Also, the media reacted to the incidents by calling on 'every ASEAN leader to send a strong individual message to Yangon.'106

\section{Observing ASEAN behaviour}

The principle of 'performance legitimacy' was thoroughly reconsidered by ASEAN leaders in the Bali declaration (Concord II) of October 2003, and soon afterwards in the ASEM5 Chairman's Statement in Hanoi of October 2004, where they made recommendations to the SPDC. The Hanoi statement was the most complete declaration that ASEAN issued regarding expectations related to Myanmar. ${ }^{107}$ The substance of the message was new, with all stakeholders engaged in that country being invited to join forces to guarantee positive consequences for reconciliation. It gave weight to the NDL, its leader and to other movements, which opposed the junta, and indicated that there were forums to be freed up for a 'genuine debate.'

\section{Not so 'moderated' and not so 'accommodating': Myanmar's accession to ASEM in 2004}

The EU's insistence on sanctioning Yangon and ASEAN's refusal to accommodate the EU position resurfaced. Together with expressing concern about the SPDC, the 2004 Hanoi (ASEM5) Statement 'warmly welcomed the Union of Myanmar' at the Asia-Europe Meeting. ${ }^{108}$ Diplomatic crises followed and two meetings of ASEM finance ministers were cancelled. On ASEAN's side, there had been preparatory talks on Myanmar's admittance prior to the Hanoi summit. The Indonesian Foreign Minister pretended to instruct that no political conditions had to be attached. The Cambodian Prime Minister affirmed that his country would not have joined ASEM without the other two new ASEAN members (Laos and Myanmar) being accepted at the same time. Before the Hanoi summit, in August 2004, Myanmar's Prime Minister (General Khin Nyunt) met Vietnam's Prime Minister (Phan Van Khai) to discuss Yangon's participation. The meeting was attended by Hanoi-based ambassadors and ASEAN members' diplomats, all demonstrating the extent of ASEAN's great solidarity. ${ }^{109}$ On the EU side, the Council conceded the presence of Myanmar's representatives 'where a political dialogue [was] conducted that directly promote[d] ... the

\footnotetext{
104 Myanmar (Burma), <http://www.britannica.com/EBchecked/topic/916894/Myanmar-Burma-Year-In-Review2003>, accessed October 2013.

${ }^{105}$ Haacke, 'Myanmar and ASEAN, p. 52.

${ }^{106}$ K. Siang, <http://dapmalaysia.org/all-archive/English/2003/sepo3/lks/lks2650.htm>, accessed October 2013.

107 ASEM in its Tenth Year, 2006.

108 The 2004 Hanoi (ASEM5) Statement, p. 10.

109 The Vietnam News, 9 August 2004. Fitriani, op cit, pp. 5-8.
} 
rule of law in Burma/Myanmar.' At the same time, it expanded the sanctions. ${ }^{110}$ Why were ASEAN members tolerating a pariah state to the point of offering it inclusion at the AsiaEurope Meeting after the uneasiness about Yangon had been demonstrated during the Depayin repression? It seems a paradox, although there were several reasons supporting that decision; primarily ASEAN's determination to build a completely inclusive Southeast Asian community. ASEM was an emanation of the Association and was seen as consolidating its existence. Secondly, there was 'the conviction that China's rise could positively shape East Asia only if successful counterbalanced' and, thirdly, the preoccupation that Myanmar could definitely turn to China as an alternative source of support. By 2004 Myanmar was firmly integrated into regional international society. ${ }^{111}$

\section{The limited 'openness' with regard to Myanmar}

As part of the two-pronged approach, the Council also promoted confidence-building measures aimed at giving strength to the opposition and actors at the local level, innovatively seeking to elude the involvement of governmental authorities. ${ }^{112}$ The European limited 'openness' on Myanmar had not impeded the Council from opposing the prospect of the SPDC taking its turn as chair of the ASEAN Standing Committee in 2006-7. The Council reimposed sanctions and also proposed a partial suspension. ${ }^{113}$ ASEAN members similarly claimed that the 'road map towards democracy' (originally proposed by the Thai Prime Minister in 2003) made no visible progress, and opposed Myanmar's chairmanship. ${ }^{114}$ The Philippines, Singapore, Indonesia, and Malaysia also reacted individually. The SPDC decided to act in the interest of ASEAN, which was under external pressure over Myanmar. It employed the justification that it wished to focus on the 'ongoing national reconciliation and democratization process,' 115 thus placing emphasis on Myanmar's approach to exercise its own sovereign decision and contrast outside interactions, consistently with its constitution. ${ }^{116}$

\section{Departure from non-interference}

By now, the ASEAN members had been openly discussing the situation in Myanmar among themselves as well as with the European Union and their ASEM partners. The SPDC's noncompliance was barely defended. 117 In particular, Thailand's Foreign Minister (Surin Pitsuwan) encouraged the move from the norm of non-interference with internal affairs towards a policy of flexible engagement with Myanmar. This called for growing interaction with the Burmese leaders, particularly when they took steps towards reform, and aimed to build people-to-people bridges. ${ }^{118}$ This change was largely due to the realisation that Myanmar affected ASEAN's international prestige and so, by extension, its integration project. The Association's member states were now focused on transforming their group through the preparation of the ASEAN Charter, which was going to establish ASEAN as a legal entity, modelled on the European Union.

\footnotetext{
${ }^{110}$ CCP (2004/423/CFSP).

${ }^{111}$ Hughes, 'New Security Dynamics in the Asia-Pacific: Extending Regionalism from Southesast to Northeast Asia,' op cit, p. 323 .

${ }_{112}$ CCP (2004/423/CFSP), Paragraph 5, Art. 5.

113 CCPs (2005/340/CFSP) and (2006/318/CFSP).

114 ASEAN meeting of Foreign Ministers, Cebu, the Philippines, 2005.

115 Haacke, 'Myanmar and ASEAN,' op cit.

116 <http://www.scribd.com/doc/7694880/Myanmar-Constitution-20o8-English-versio>, accessed October 2013.

117 Joint Communiqué, $39^{\text {th }}$ ASEAN Ministerial Meeting, 2006, Kuala Lumpur.

${ }_{118}<\mathrm{http}: / /$ www.visetkaew.com/wp/2013/o1/o7/thailands-surin-pitsuwan-praised-as-term-as-asean-chief-ends/>, accessed October 2013.
} 


\section{An analysis of EU behaviour}

The consideration that 'Southeast Asia was set to become one of the most dynamic growth areas in the world economy' and that 'closer relations were an economic imperative' 119 contributed towards backing a more conciliatory policy on Myanmar via EU-ASEAN relations. The EU continued to be concerned that interaction with ASEAN with regard to Myanmar should not weaken its links with the Association. Also, through both the 2001 and 2003 Commission's Communications, the European Union declared its 'strategic' intentions of raising the EU's political presence across Southeast Asia to a level commensurate with the growing global weight of an enlarged EU. In reality, the EU's political profile appeared less influential, at least in the terms enunciated by the Commission. Yet, some efforts were made to respond to the 'key priority' of further strengthening the long-standing partnership with ASEAN. ${ }^{120}$ Attempting the suspension of sanctions and compromising on Myanmar by opening up a diplomatic representation in Brussels were additionally aimed at revitalizing relations with the Association. This novel feature characterises the EU-ASEAN relationship with regard to Myanmar. As in 1997, when the Council laid emphasis on the welcoming occasion to reinforce the dialogue with the Southeast Asian countries via the new commitment regarding Myanmar, also in the following years Myanmar appears to offer occasions to the EU for re-invigorating its ties to ASEAN.

\section{7-2012}

In 2007, the autumn pro-democracy demonstrations and repression (the Suffron uprising) laid bare ASEAN's impatience with the military junta. ASEAN agreed a joint statement with the European Union urging the junta to free all political prisoners. In the Council Conclusions of October 2007, the EU warned the SPDC that a return to the situation as it was prior to the recent demonstrations was both unacceptable and unsustainable. The ASEAN-EU statement established no deadlines by which the SPDC must comply. Myanmar's media (The Irrawaddy) argued that the junta's strong man (General Than Shwe) knew 'how to play in a sophisticated way with a weak organisation like ASEAN.' ${ }^{121}$ By contrast with ASEAN's alleged low reputation, Singapore's Foreign Minister indicated that 'ASEAN planned to use its moral authority to get all of the political parties in Burma to engage in a genuine dialogue.'122 Singapore held ASEAN's chair and was in a position to seek to influence others' views. Myanmar's Prime Minister, Thein Sein, argued that the Burmese situation was a 'domestic affair,' reconfirming the junta's traditional code of conduct. The ASEAN member states also reacted individually to the Suffron incidents. Singapore's senior minister (Goh Chok Tong) threatened to cease investment in Myanmar, regarding political reform as a precondition for their mutual economic interaction to continue. ${ }^{123}$ The Philippines' Senate adopted a resolution urging the EU and ASEAN to end the SPDC's repression of people. ${ }^{124}$ The European Union acknowledged the changes occurring in ASEAN's attitudes, and the Association's efforts to influence the Burmese authorities to embrace the transition to democracy, ${ }^{125}$ the whole pointing at the novel stance of

\footnotetext{
${ }_{119} \operatorname{COM}(2003) 399$.

$120 \mathrm{COM}(2001) 469$.

12122 November 2007, <http://www.asianews.it/news-en/Myanmar-playing-“tricks"-with-the-internationalcommunity-10873.html $>$, accessed October 2013.

122 G. Yeo, CAN (20 October 2007). <http://www.altsean.org/Research/Saffron\%2oRevolution/SRInternational1.php $\geq$

123 Haacke, 'The Myanmar imbroglio and ASEAN: heading towards the 2010 elections,' op cit, p.163.

124 Senate of the Philippines Resolution No. 19 adopted September 26, 2007.

125 Council conclusions, 15-16 October 2007.
} 
encouraging Myanmar's better governance. The EU developed a strategy of targeted sanctions combined with a policy of a partial trade embargo and limited development cooperation.

\section{The EU's targeted policy and development cooperation}

In the new combined policy, the Council increased its pressure on the SPDC, and agreed on measures directed at state-owned industries. It also introduced a ban on the creation of joint ventures with blacklisted establishments. ${ }^{126}$ In parallel, the EU confirmed the continuation of the substantial humanitarian aid programmes. The European Commission released the Country Strategy Paper on Myanmar, in 2007, with an indicative budget of $€ 65$ million. It resulted from the 'European Consensus on Development,' agreed on 20 December 2005 between the European Commission, the European Parliament and the EU Council, which identified poverty reduction as the main priority of EC development assistance. One of the objectives of the policy of dialogue with Myanmar was 'strengthening civil society' and intensifying 'community participation' in order to increase local non-state actors' contribution to the development process' to take place in Myanmar. ${ }^{127}$ A former EU Special Envoy for Myanmar (2007-2011), interviewed by the author, expressed a positive judgement

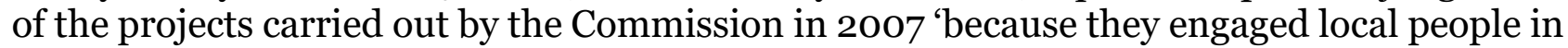
collective activities, aiming at building trust and enhancing the interactions among communities.' 128 The EU also tried to promote negotiations on a EU-ASEAN Free Trade Agreement (FTA), in 2007, but these failed to materialise partially due to the political instability and related problems in Myanmar. ${ }^{129}$

\section{ASEAN (and the EU) encouraging better governance}

In 2007, ASEAN saw no progress in the SPDC's governance, no dialogue with the political parties; there was no evidence of political reforms or a transition to democracy. In Beijing, in 2008, in the ASEM 7 Chair's statement, ASEAN leaders encouraged the 'government to engage all stakeholders in a inclusive political process in order to achieve national reconciliation and economic and social development.'130 This attitude of trying to convince the SPDC to embrace changes was expanded further at the $14^{\text {th }}$ ASEAN's summit in Thailand in 2009. A decisive call for the 'participation of all political parties' and for 'free and fair' general elections in 2010 respectively reinforced ASEAN's and ASEM's request for a shift in Myanmar's conduct of domestic affairs. ${ }^{131}$ ASEAN's and EU's demand that the SPDC engage in promoting consensus was heightened in reaction to the court verdict passed on Suu Kyi, in August 2009, which added 18 months to her house arrest. The ASEM partners prompted Myanmar's authorities to step 'towards a legitimate, constitutional and civilian system of government.' 132 The ASEAN argument that the elections must convince the international community that they were transparently prepared was a further reminder issued in late 2009. ${ }^{133}$ The European Union recommenced boosting its targeted policy in response to the court's verdict on Suu Kyi, with sanctions this time focused on the members of the judiciary

\footnotetext{
${ }^{126} \mathrm{CCP}(2007 / 750 / \mathrm{CFSP})$.

127 The EC/Burma/Myanmar Strategy Paper (2007-2013), op. cit., p. 19.

128 Turin, January 2013.

${ }^{129}$ See deFlers op cit, p. 7, note 20.

${ }_{130}$ ASEM 7 Chair's statement, Beijing, 2008, paragraph 12.

${ }^{131}$ The dialogue generated informal seminars on Human Rights, held annually since 1998.

132 Chairman's Statement (ASEM8), Brussels, 2010, paragraph 73.

133 Chairman's Statement, ASEAN, Cha-am Hua Hin, Thailand, 2009, paragraph 46.
} 
responsible for the decision. ${ }^{134}$ It also recognised the progress promised by the 'promulgation of a new electoral law.'135

Yet, faulty party registrations, defective laws and the boycott of the NLD regarding the November 2010 elections were the specific focus of the meeting of ASEM Foreign Ministers held in Hungary in 2011. The EU policy re-extended the sanctions ${ }^{136}$ and updated the list of persons and entities subject to restrictive procedures, in line with its focused strategy. It made clear to the Myanmar junta that the 'non-association' of the government's appointees with the military was vital to the dialogue with the international community. Aiming at encouraging 'progress in civilian governance,' the EU lifted the suspension of high-level bilateral governmental visits to Myanmar for a period of twelve months, and freed from these restrictions the new members of the government who were unaffiliated with the military. The reforms initiated by Thein Sein in his new role of President since March 2011 and the subsequent April 2012 by-elections showed Myanmar's willingness for change to be put into practice. The transformations were publicly recognized by ASEAN and the European Union, which invited European companies to explore new opportunities for trade and investment and to promote the highest standards of integrity and Corporate Social Responsibility. 137 The European Union solicited further compliance and renewed, and also lifted, certain restrictive measures. ${ }^{138}$ Myanmar's authorities' signing on 20 September 2013, in Brussels, of the Additional Protocol on the application of safeguards in connection with the Treaty of Non-Proliferation of Nuclear Weapons was a further sign of a partnership in the making between the EU and Myanmar.

\section{Assessing EU behaviour}

EU behaviour vis-à-vis Myanmar since the Suffron uprising evolved. EU ministers declared themselves ready to discuss Burmese matters with their Myanmar counterparts at several possible meetings, including regional, ministerial ASEAN-EU, ASEM, or at bilateral gatherings at the margins of these. The EU delivered the Strategy Paper on Myanmar regarding 2007-2013.139 Both the aired meetings and the strategy paper hinged on ASEAN. ASEAN was also key to the subsequent EU's policy-making on Myanmar, namely the 2013 Comprehensive Framework. In that document, the EU pledged to assist Myanmar's government with rebuilding its place in the international community, and also promised to support it in reaping the benefits of integration within ASEAN. ${ }^{140}$ Again, it appears that Myanmar helped to reinforce the long-lasting EU-ASEAN relationship rather than endangering the EU's ties with ASEAN.

\section{Conclusions}

EU behaviour vis-à-vis Myanmar via EU-ASEAN has displayed an element of continuity; the EU has constantly demonstrated concern to avoid the Myanmar issue destabilising its relations with ASEAN. As the interviewees confirmed, it was clear that the desire to get away from influential China, together with the appeal for new partners were crucial in bringing about the changes. These have been identified as falling into three different phases. First,

\footnotetext{
134 CCP (2009/615/CFSP).

135 Council Decision (2010/232/CFSP).

${ }_{136}$ Council Decision (2011/239/CFSP).

137 Council Decision (2011/5O4/CFSP), paragraph 7.

${ }_{138}$ Council Decision (2012/225/CFSP).

139 The EC/Burma/Myanmar Strategy Paper (2007-2013), op. cit.

140 Council conclusions, 22 July 2013, p. 2.
} 
the EU insisted on sanctioning Myanmar, and ASEAN on rejecting the censure of Yangon's regime by its EU dialogue partner. This dynamics was well-established during 1991-1997. The EU's obstinacy in applying negative measures corresponded to ASEAN's inflexibility in defending its opposition to the 'external interference' of the EU and to its good governance claim. Second, the EU moderated criticism of Myanmar and ASEAN distanced itself from rejecting the censure of the regime by its EU dialogue partner. These changes occurred during 1998-2006. The Council of the European Union tried to use the two-pronged strategy of suspension and renewal of sanctions, and ASEAN demonstrated a change by starting to discuss Myanmar's problems during its meetings with the EU, expressly making recommendations, and progressively relaxing the non-interference principle. The article upheld that the latter change was backed by the Association's preoccupation with the fact that Myanmar's affairs might negatively impact on ASEAN's integration project and standing. Third, the EU employed targeted sanctions and limited development cooperation, while ASEAN encouraged Myanmar's better governance. These policies evolved during 2007-2012. The Commission's Country Strategy Paper on Myanmar proved that the EU was less obstinate and intractable in its position of merely continuously sanctioning Myanmar. It showed some openness in promoting local (non-state) actors' contribution to the democratisation process as an interviewee has stated. ASEAN, concomitantly, several times insisted to the military junta that a transition to democracy was expected by the Association.

Informed by the idea of the evolution of the EU profile in world affairs through its political connections with ASEAN, this article illuminates the Commission's 'attention to the EU's perceived growing global weight' and call 'to raise its profile' across Southeast Asia. However the evidence leads to the conclusion that the EU has not been punching to its weight in the region. ${ }^{141}$

Investigations on Asian perceptions of the EU agree that the European Union is a global political actor 'somewhere else' in the world. ${ }^{142}$ With regard to Myanmar, as the Burmese interviewees indicated, the EU was an 'unknown' actor, or an agent which attracted a sort of negative publicity. However, through the latest partnership strategy, the EU is finding new ways to raise its visibility as a motivating and inspiring referee. While many scholars have dwelled on the difficulties caused by the Myanmar issue to the EU-ASEAN ties, this investigation has demonstrated the extent to which the Myanmar case has in fact helped to reinforce the long-lasting EU-ASEAN relationship

${ }^{141}$ See also Cameron, op cit., pp. 41-2.

${ }^{142}$ See M. Holland, et al (eds) The EU through the Eyes of Asia, Warsaw, University of Warsaw, 2007. 